\title{
Evaluation of the Therapeutic Potential of Canine Yolk Sac Cells in Dogs with Hips Dysplasia
}

\author{
Daniel Tonin Benedetti1 ${ }^{1,3}$, Daniela Amstalden², Nathia Nathaly Rigoglio ${ }^{1}$, Danilo Custódio Marques*1, \\ Maria Angelica Miglino ${ }^{1}$ and Paula Fratini ${ }^{1}$ \\ ${ }^{1}$ Department of Surgery, School of Veterinary Medicine and Animal Science, Brazil \\ ${ }^{2}$ Rusvet Image Diagnostic Center, Brazil \\ ${ }^{3}$ VetPrado Veterinary Hospital, Brazil

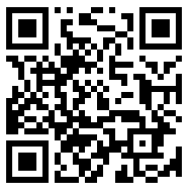

*Corresponding author: Maria Angelica Miglino, Department of Surgery, School of Veterinary Medicine and Animal Science, Brazil

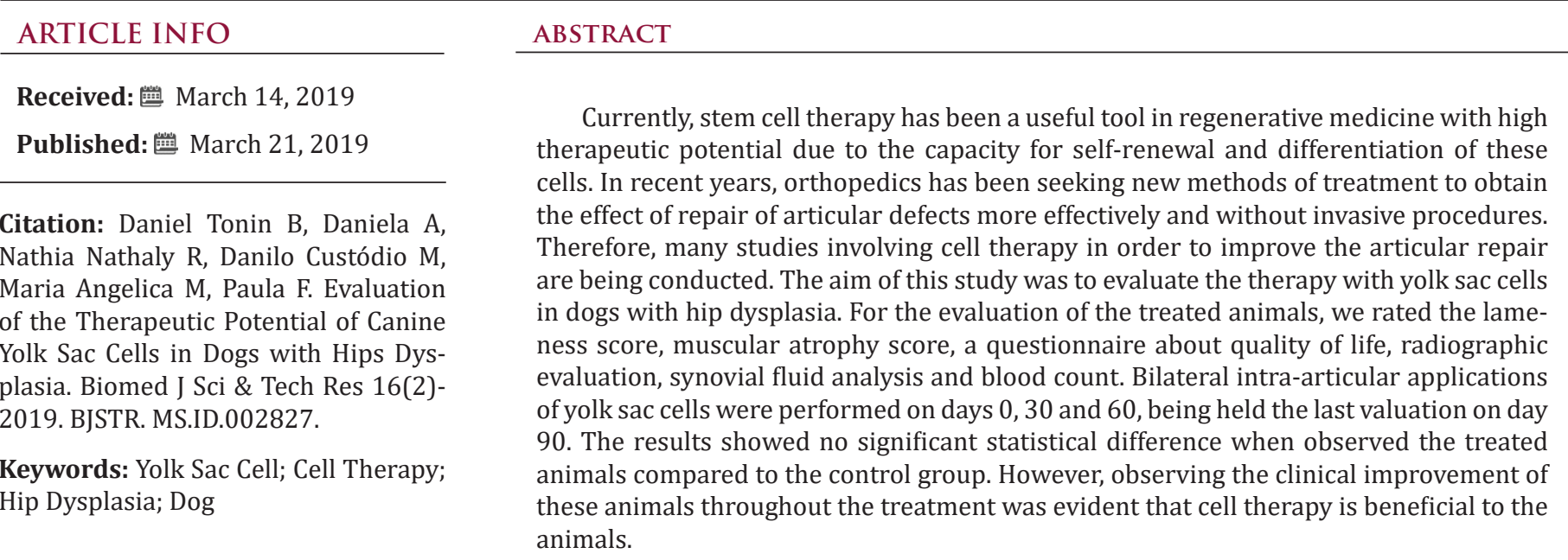

\section{Introduction}

In the veterinary medicine, the Hip Dysplasia (HD) has been presented as one of the main osteo-articular pathologies that affect the dogs, being responsible for about $50 \%$ of specialists' visits [1]. The prevalence varying from 0.0 to $71,8 \%$. There is a strong association between the clinical diagnosis of hip status and veterinary care and mortality related to HD [2]. Since the earliest reports of HD, there are more papers written about this disease than about any other disease related to small animal orthopaedics [3]. HD is a change in the development of the femur that presents varying degrees of hip laxity, progressive remodeling of the hip structures and subsequent development of Osteoarthritis (OA) [4]. Hip laxity allows subluxation of the joint during growth, resulting in abnormal development of the acetabulum, neck and femoral head. Repetitive subluxation and reduction lead to excessive cartilage wear and damage to the dorsal acetabular ridge [5]. Although HD has a recessive, intermittent and polygenic genetic basis [6], multiple environmental factors modify the expression of this predisposition, affecting the way it manifests itself and its severity [7-10]. Many studies have reported heritabilities of HD (0.011.75) [11] and some have observed favourable genetic progress in reducing expression $[11,12]$. It can be observed in several breeds of dogs, however, it is prevalent in large dogs and fast growing, for example, Labrador Retriever, New found lands, Rottweilers, St. Bernard and Mastiffs. Some breeds of terriers, as well as Bulldogs and Pugs are also predisposed [13-15].

The history and clinical signs of affected animals include gait abnormalities such as lameness, short steps, rabbit leap, as well as exercise intolerance and difficulty in getting up and climbing stairs [16]. Among the treatment modalities, surgical and conservative ones are described. This second one is restricted to weight control, exercise restriction, physical rehabilitation, pain management and administration of nutraceutical supplements [17-21]. The surgical 
procedures described in animals are juvenile pubic sinfisiodesis $[19,22]$, colocephalectomy [16], triple pelvic osteotomy [23], total hip replacement [19,24] and capsular denervation [3]. Currently, cell therapy has been a useful tool in regenerative medicine with high therapeutic potential due to the capacity for self-renewal and differentiation of these cells. In recent years orthopedics has been looking for new methods for a treatment that obtains the effect of repairing joint defects more effectively and without invasive procedures. Therefore, many studies involving stem cells aimed at improving joint repair are being performed [25]. Mesenchymal stem cells can be extracted from various organs, expanded in culture as a cell adherent population and induced to differentiate into multiple cell types. Based on the observation that mesenchymal stem cells can pass through adipogenic, osteogenic and chondrogenic differentiation, an attempt was made to use mesenchymal cells for tissue repair in vivo. The present study aims to evaluate the therapeutic potential of the use of canine yolk sac stem cells in the clinical-surgical treatment of hip dysplasia in this species.

\section{Material and Methods}

This study was submitted and approved by the Committee of Ethics in the Use of Animals of the School of Veterinary Medicine and Animal Science (FMVZ-USP) under protocol n: 2401/2011.

\section{Dogs}

Eight animals of the canine species were selected, with no preference of race, sex and age, coming from the private clinics of São Paulo, with bilateral coxofemoral dysplasia confirmed by a recent radiographic examination. These animals should not present any other orthopedic disease and have the ability to wander normally. After the selection, the animals were randomized in control group and treated group (YS).

\section{Clinical Evolution}

In order to evaluate the efficacy of the cellular therapy, the clinical evolution of the animals was analyzed by means of a comparison between the pre- and post-treatment evaluations, the latter being on days 30, 60 and 90 days, as well as the simple x-ray of the hip joint to evaluate the evolution of the arthrosis, complete blood count to evaluate possible hematological alterations resulting from the treatment, and analysis of the synovial fluid to evaluate the changes present directly in the fluid of this joint.

\section{Surgery, Cell Therapy and Tests}

All animals were submitted to 8 hour water and food fasting for the sedation and anesthesia procedures, in which Meperidine $(0.4$ mg / kg, intramuscular, União Química, Brazil) and Propofol (4.0 mg / kg, intravenous, Propovan $®$, Cristália, Brazil) for subsequent radiographic examination with cranio-caudal projection of the coxofemoral joint. After this examination, with the animals in lateral decubitus, tricotomy and asepsis of the pelvic region were performed near the hip joint. A Thuoy 19G needle (Terumo Corporation, Japan) was used percutaneously to reach the hip joint to collect synovial fluid, which was filled into EDTA (anticoagulant) -containing tubes. Sterile saline solution $(0.5 \mathrm{ml})$ was then applied to the joint in the animals of group $\mathrm{C}$, and canine Yolk Sac Cells (YS) $(0.5 \mathrm{ml} / 1 \mathrm{x} 107$ cells). The same procedure was performed on the contralateral limb. A blood sample was collected by venous puncture of the jugular and packed in tubes containing EDTA. After the procedures, all animals received analgesic and antibiotic medication, Dipirone $(1 \mathrm{ml}$ / animal, subcutaneous route, Algivet $\AA$, Vetnil, Brazil) and Enrofloxacin (5mg / $\mathrm{kg}$, single dose subcutaneous use, Baytril 10\% ®, Bayer Laboratory SA, Brazil). Three applications (day 0, 30 and 60 after application) and four evaluations (day 0, 30, 60 and 90 after application) of each patient were performed on each item. For this study the animals were followed during the 90 days, the data were evaluated by t-test and two-tailed test, being adopted as value of statistical significance $\mathrm{p}<0.05$.

To evaluate the scores of muscle atrophy, claudication and Ortolani test were assigned values from 0 to 4,0 being the absence of the problem and 4 the maximum degree observed, according to Hudson [26]. For the quality of life questionnaire points were distributed from 12 to 48 , being 48 considered as an excellent quality of life. For the analysis of the synovial fluid the physical and chemical aspects evaluated within the acceptable values for the species were observed, as well as performed in the hemogram evaluation. The canine yolk sac cells were obtained from the cell bank of the Stem Cell Laboratory of the Anatomy Department, Department of Surgery, FMVZ-USP. These cells were previously collected, characterized and stored by our research group in previous studies. These cells were thawed for application to animals in the treated group.

\section{Results}

No radiographic changes were observed between the groups before and after treatment. There were also no changes in hematological examinations after the procedures. There were also no reports of worsening of claudication of the animals, remaining stable. The Ortolani test (Graph 1) and quality of life questionnaire (Graph 2) were the most representative evaluations in the improvement of treated animals. A clinical improvement of SV animals during the 90 days of the treatment can be observed, where the animals left a very low score and obtained an improvement, showing a significant statistical difference at day 90. For example, for the Ortolani test, there were animals in the treatment group that were very sensitive to pain, creped, even resistant to the test, which after cell therapy showed no more unpleasant symptoms when handled. According to the owners, these animals that once stood for long periods at rest without locomotion, returned to practice normal activities such as games and down steps, having a improvement in the quality of life. 

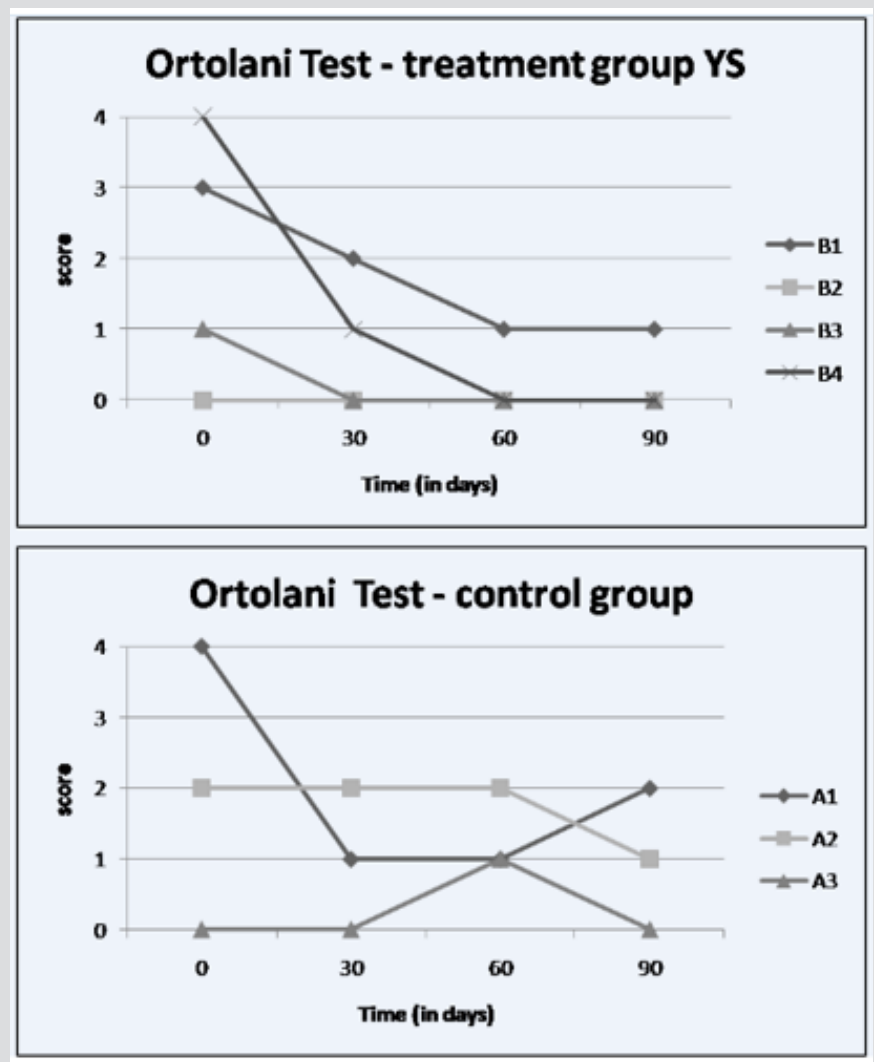

Graph 1: Evaluation of treated animals and control according to the Ortolani Test. Comparing the animals of group A (control) and B (therapy) we can observe a significant improvement of the animals that received yolk sac cells after 30 days of application.
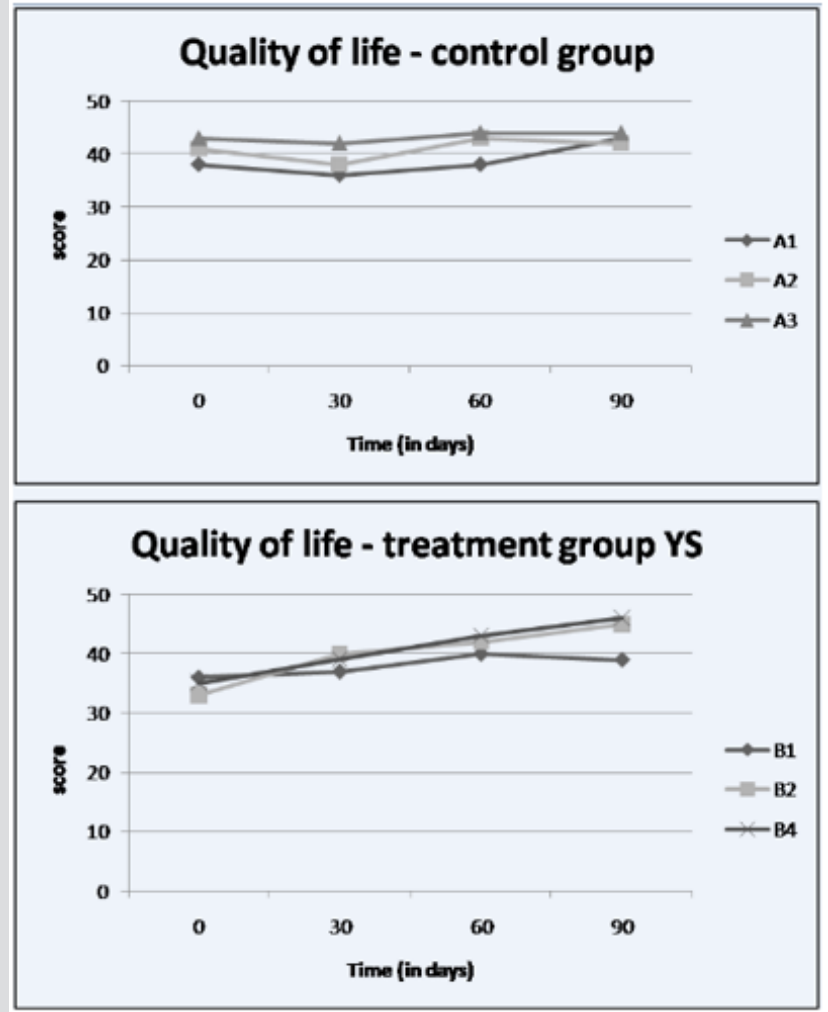

Graph 2: Questionnaire on the quality of life of animals after treatment. It was possible to observe, according to veterinary evaluation and monitoring of the owners, that there was an improvement in the quality of life of the animals treated with yolk sac cells (B) when compared to the control animals (A), mainly after 60 days of treatment. 


\section{Discussion}

Hip dysplasia was the joint disease of choice because it had the highest prevalence of joint affections causing degenerative joint disease in dogs worldwide. Its main feature is the abnormal formation of the coxofemoral joint with different degrees of dislocation and subluxation, and its prevalence is higher in animals of large and giant races, although it has been observed in the terrier breeds, as well as Bulldogs and Pugs [13-15]. The cause of the hip dysplasia is multifactorial and the treatments are diverse and controversial [27]. The only surgery that treats hip dysplasia per se is the total hip replacement $[19,24]$. Surgery is often used to ameliorate the discomfort of hip dysplasia. The surgical procedure often depends on the age of the animal at the time of admission, the preference and recommendation of the surgeon, the financial investment, the potential risks and the necessary care in the postoperative period. However, it is still unclear whether this will result in a better outcome and hence whether it is the most recommended [28]. Dogs as experimental models of stem cell treatments have provided preclinical information relevant to treatments in both human medicine and veterinary medicine [29]. Another important aspect is the great growth of cell therapy in the veterinary clinic for the treatment of several canine diseases [30], since Mesenchymal Stem Cells (MSCs) have shown promising results in preclinical studies and in the central nervous system and in cartilaginous bone defects [31].

Autologous MSCs demonstrated therapeutic effects in experimental studies, including improved tendon healing in horses and increased regeneration of meniscal tissue and delayed progression of OA in goat model [32,33]. However, stem cells of fetal origin are more accessible because they are obtained from extra embryonic tissue, such as the yolk sac [34], placenta [35], amnion [36] and chorion [37], which are usually discarded after birth. Fetal stem cells have low immune responses, since they are at the maternal-fetal interface [38]. In the present study we could observe the low immune response of this cell type, since none of the treated animals showed signs compatible with this problem. Fetal stem cells also show rapid growth and good plasticity [39] and can replace adult and embryonic stem cells in cell therapy [40]. Moreover, they are able to differentiate into specific cells such as cardiomyocytes, as well as to present the differentiation properties in already established osteogenic, adipogenic and chondrogenic lines [41], making these cells an alternative source of multipotent cells [42]. For these reasons we choose for this study the therapy with yolk sac cells, which has properties of mesenchymal progenitor cells, plasticity and potential do differentiation $[34,43]$ for the treatment of joint diseases in the canine model, aiming to validate this therapy in articular diseases, such as, for example, the hip dysplasia, enabling a new clinical management in these cases .

In order to isolate progenitor cells capable of maintaining the hematopoietic lineage in vitro, great interest has been gained in obtaining stem cells from the yolk sac. When these cells were cultured in specific culture medium, the yolk sac progenitor cells were able to differentiate into bone, cartilaginous and muscular tissue [34]. In view of these results, we believe that these cells presented efficient osteogenic and chondrogenic differentiation capacity in order to positively collaborate with the results obtained in this work. Although there was no statistically significant difference for the quality of life test when comparing the treated group (SV) with the control group (C), the clinical improvement of the SV group was observed throughout the treatment, where the animals that presented a very low score, they obtained improvement of this score during the treatment, showing a significant improvement on day 90. The fact that no statistical difference was observed in the quality of life questionnaire could be due to the score of the animals of group $\mathrm{C}$ presenting on day 0 (where there was still no interference from the treatment) a score much higher than the animals in the SV group. Another important source studied are Bone Marrow-Derived Mesenchymal Stem Cells (BMSCs), they have been the subject of important scientific research due to their relevant properties for use in cell therapy, such as their great ability to differentiate into osteoblasts [44].

We can correlate the results obtained for this cell type with the results obtained with yolk sac cell therapy since the two strains havea compromise with hematopoiesis at different stages of development. During development, yolk sac stem cells temporarily migrate to the fetal liver and eventually locate in the bone marrow, a permanent site of blood cell formation. With this departure from stem cells the yolk sac progressively atrophies throughout gestation [45]. BMSCs have great ability to differentiate into osteoblasts, both in vitro and in vivo, which led to their clinical use in pilot studies for hereditary bone disorders and osteogenic deficiencies in different animal species [29,46]. Queiroz et al. [25] used bone marrow cells for the treatment of hip dysplasia in dogs and no statistical difference was found between the control and treated groups, similar to the one in this study, where the animals treated by cell therapy demonstrated an improvement in the degree of claudication, in the Ortolani test and mainly of the evaluation of quality of life performed by the owners, but without statistical significance. A randomized, doubleblind, multicenter American study used stem cells derived from adipose tissue in dogs with coxofemoral dysplasia, but the authors report a significant difference in the results obtained between the two groups.

The animals in the treatment group presented a post-treatment clinical score at all times for the positive evaluations, being higher than the control group [47], a result different from the one found in this study, where there was no statistical difference in the comparison group treatment and control. There is a general consensus in the consulted literature of the benefits of cell therapy for the most diverse pathologies. There are few jobs that utilize the yolk sac stem cell. It is a new source of readily available stem cells, induces a low immune response in the recipient animal and can be 
cultured and expanded in vitro without altering its plasticity. In this work we can verify its beneficial use in articular pathologies in the canine species, being proved the benefits of these two cell types in the hip dysplasia. There is a general consensus in the consulted literature of the benefits of cell therapy for the most diverse pathologies. There are few studies that use the yolk sac stem cell and are therefore a new source of easily obtained stem cells that induce a low immune response in the recipient animal and can be cultured and expanded in vitro without alteration of their plasticity . In this work we can verify its use in articular pathologies in the canine species, being proved the benefits of this cellular type in the hip dysplasia. Studies are being conducted to see the actual effect of stem cells on cartilage regeneration. It is known that the main effect of stem cells on the hip dysplasia, due to being a disease caused by a change in biomechanics, is the anti-inflammatory action, in which the patients' quality of life improves and without the use of drugs for long periods of time. The stem cell can used to analgesic in dogs with the hip dysplasia. Treatment of dysplasia is often multifactorial, therefore the use of stem cells enters as a form of treatment, and may or may not be associated with other treatment modalities.

\section{Conclusion}

Positive changes were observed in the animals treated with yolk sac cells when performing the Ortolani test and quality of life questionnaire. No evolution of osteoarthrosis was observed in the animals submitted to cell therapy. There were no adverse effects on the use of yolk sac cells in this treatment. We conclude that although more confirmatory studies are needed, therapy with yolk sac cells is a promising tool for treating hip dysplasia in dogs.

\section{References}

1. Schmaedecke A (2004) Estudo quantitativo das fibras nervosas do periósteo acetabular em cães. 95 f. Dissertação (Mestrado em Ciência Animal) - Faculdade de Medicina Veterinária e Zootecnia. Universidade de São Paulo São Paulo.

2. Malm S, Fikse WF, Danell B, Strandberg E (2008) Genetic variation and genetic trends in hip and elbow dysplasia in Swedish Rottweiler and Bernese Mountain Dog. Journal of Animal Breeding and Genetics 125(6): 403-412.

3. Ferrigno CRA, Schmaedecke A, Oliveira LM, D'Ávila RS, Yamamoto EY, et al. (2007) Denervação acetabular cranial e dorsal no tratamento da displasia coxofemoral em cães: 360 dias de evolução de 97 casos. Pesq Vet Bras 27(8): 333-340.

4. Syrcle J (2017) Hip Dysplasia: Clinical Signs and Physical Examination Findings. Vet Clin North Am Small Anim Pract 47(4): 769-775.

5. Dassler CL (2003) Canine hip dysplasia: diagnosis and non-surgical treatment, in Slatter D (ed): Textbook of small animal surgery ( $3^{\text {rd }}$ edn.). Philadelphia PA Saunders 2019-2020.

6. Sommer EL, Fratocchi CLG (1998) DisplasiaCoxofemoral. Rev Educ Cont 1: 031-035.

7. Ginja MM, Silvestre AM, Gonzalo Orden JM, Ferreira AJ (2010) Diagnosis, genetic control and preventive management of canine hip dysplasia: a review. Vet J 184(3): 269-276.

8. Krotscheck U, Tohundter T (2010) Pathog enesis of hip dysplasia. In Bojrab MJ, Monnet E, editors. Mechanisms of disease in small animal surgery. $3^{\text {rd }}$ edition Jackson (WY) Teton New Media, pp. 636-645.
9. Krontveit RI, Nødtvedt A, Sævik BK, Ropstad E, Trangerud C, et al. (2012) Housing and exercise-related risk factors associated with the development of hip dysplasia as determined by radiographic evaluation in a prospective cohort of Newfoundlands, Labrador retrievers, Leonbergers, and Irish wolfhounds in Norway. Am J Vet Res 73(6): 838846 .

10. Smith GK, Karbe GT, Agnello KA (2012) Pathogenesis, diagnosis, and control of canine hip dysplasia. In: Tobias KM Johnston SA editors. Veterinary surgery small animal $1^{\text {st }}$ edition. St Louis (MO): Elsevier, pp. 824-848.

11. Oberbauer AM, Keller GG, Famula TR (2017) Long-term genetic selection reducedprevalence of hip and elbow dysplasia in 60 dog breeds. PloS one 12: e0172918.

12. Lewis TW, Blott SC, Woolliams JA (2013). Comparative analyses of genetic trends and prospects for selection against hip and elbow dysplasia in 15 UK dog breeds. BMC Genetics 14: 16.

13. Brass W (1989) Hip dysplasia in dogs. J Small Anim Pract 30: 166-170.

14. Fries CL, Remedios AM (1995) The pathogenesis and diagnosis of canine hip dysplasia: a review. Can Vet J 36(8): 494-502.

15. Kapatkin AS, Fordyce HH, Mayhew PD, Smith GK (2002) Canine hip dysplasia: the disease and its diagnosis. Comp Cont Edu Pract Vet 24(7): 526-538.

16. Rawson EA, Aronsohn MG, Burk RL (2005) Simultaneous bilateral femoral head and neck ostectomy for the treatment of canine hip dysplasia. J Am Anim Hosp Assoc 41(3): 166-170.

17. Tomlinson J, McLAughlin R (1996) Medically managing canine hip dysplasia. Vet Med 9(1) 8-53.

18. Dycus DL, Levine D, Marcellin-Little DJ P (2017) Physical Rehabilitation for the Management of Canine Hip Dysplasia. Vet Clin Small Anim 47(4): 823-850.

19. Roush JK (2012) Surgical therapy of canine hip dysplasia. In: Tobias KM, Johnston SA, editors. Veterinary surgery small animal. St Louis (MO): Elsevier Saunders, pp. 849-864.

20. KuKanich B, Bidgood T, Knesl O (2012) Clinical pharmacology of nonsteroidal anti- inflammatory drugs in dogs. Vet Anaesth Analg 39(1): 69-90.

21. Vandeweerd JM, Coisnon C, Clegg P, Cambier C, Pierson A, et al. (2012) Systematic review of efficacy of nu-traceuticals to alleviate clinical signs of osteoarthritis. J Vet Intern Med 26(3): 448-56.

22. Dueland RT, Adams WM, Fialkowski JP, Patricelli AJ, Mathews KG, et al. (2001) Effects of pubic symphysiodesis in dysplastic puppies. Vet Surg 30(3): 201-217.

23. Schulz KS, Dejardin LM (2003) Surgical treatment of canine hip dysplasia. In: SLATTER, D. Textbook of small animal surgery 3ed. Philadelphia: Saunders Cap 145 :2029-2059.

24. Olmstead ML, Hohn RB, Turner TM (1983) A five-year study of 221 total hip replacements in the dog. J Am Vet Hosp Med Assoc Schaumburg 183(2): 191-194.

25. Queiroz RA, Almeida EL, Silva MMS, Lima ER (2010) Efeito das células tronco autógenas nas doenças articulares degenerativas displásicas. Estudo em cães. In: JORNADA DE ENSINO PESQUISA E EXTENSÃO 10 Recife.

26. Hudson J, Slater MR, Taylor L, Scott HM, Kerwin SC, et al. (2004) Assessing repeatability and validity of a visual analogue scale questionaire for use in assessing pain and lameness in dogs. Am J Vet Res 65(2): 1634-1643.

27. Barros SVS, Del Carlo, RJ Viloria MI (2001) Auto enxerto percutâneo de medula óssea II. Reparação de falhas segmentares produzidas no rádio de coelhos. Cienc Rural 31(4): 627-632.

28. Bergh MS, Budsberg SC (2014) A systematic review of the literature describing the efficacy of surgical treatments for canine hip dysplasia (1948-2012). Vet Surg 43(5): 501-506. 
29. Lima SAF, Wodewotzky TI, Lima Neto JF (2012) Diferenciação in vitro de células tronco mesenquimais da medula óssea de cães em precursores osteogênicos. Pesq Vet Bras 35(5): 463-469.

30. Martins GL, Teixeira MF, Beserra Junior RQ (2014) Células tronco mesenquimais: características, cultivo e uso na Medicina Veterinária. Rev Bras Higi San Anim 8(2): 81-202.

31. Lee KS, Nah JJ, Lee BC, Lee HT, Lee HS, et al. (2013) Maintenance and characterization of multipotent mesenchymal stem cells isolated from canine umbilical cord matrix by collagenase digestion.Res. Vet Sci 94(1): 144-151.

32. Murphy JM, Fink DJ, Hunziker EB, Barry FP (2003) Stem cell therapy in a caprine model of osteoarthritis. Arthritis Rheum 48(12): 3464-3474.

33. Nixon AJ, Dahlgren LA, Haupt JL, Yeager AE, Ward DL, et al. (2008) Effect of adipose-derived nucleated cell fractions on tendon repair in horses with collagenase-induced tendinitis. Am J Vet Res 69(7): 928-937.

34. Wenceslau CV, Miglino MA, Martins D, Ambrósio CE, Lizier NF, et al. (2011) Mesenchymal progenitor cells from canine fetal tissues: yolk sac, liver, and bone marrow. Tissue Eng. Part A 17(17-18): 2165-2176.

35. Parolini 0, Caruso M (2011) Review: preclinical studies on placentaderived cells and amniotic membrane: Na update. Placenta 25: 51865195.

36. Uranium MF, Valentini L, Lange-Consiglio A (2011) Isolation proliferation cytogenetic and molecular characterization and in vitro differentiation ptency of canine stem cells from foetal adnexa: a comparative study of amniotic fluid, aminion, and umbilical cord matrix. Mol Reprod Dev 78(5): 361-373.

37. Fukuchi Y, Nakajima H, Sugiyama D, Hirose I, Kitamura T, et al. (2004) Human placenta derived cells have mesenchymal stem/progenitor cell potential. Stem Cell 22(5): 649-658.

\section{ISSN: 2574-1241}

DOI: 10.26717/BJSTR.2019.16.002827

Maria Angelica Miglino. Biomed J Sci \& Tech Res

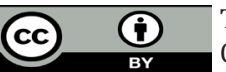

This work is licensed under Creative Commons Attribution 4.0 License

Submission Link: https://biomedres.us/submit-manuscript.php
38. Mihu CM, Rus Ciucă D, Soritău O, Sușman S, Mihu D, et al. (2009) Isolation and characterization of mesenchymal stem cells from the amniotic membrane. Rom J Morphol Embryol 50(1): 70-73.

39. Miki T, Strom SC (2006) Amnion-derived pluripotent/multipotent stem cells. Stem Cell Rev 2(2):1 33-142.

40. Marcus AJ, Wodbury D (2008) Fetal stem cells from extra-embryonic tissues: do not discard. J Cell Mol Med 12(3): 730-742.

41. Kim J, Kang HM, Kim H, Kim MR, Kwon HC, et al. (2007) Ex Vivo characteristics of human amniotic membrane-derived stem cells. Cloning and Stem Cells 9(4): 581-594.

42. Yen B L, Huang HI, Chien CC, Jui HY, Ko BS, et al. (2005) Isolation of multipotent cells from human tern placenta. Stem Cell 23(1): 3-9.

43. Fratini P, Carreira AC, Alcântara D, Oliveira e Sillva FM, Rodrigues MN, et al. (2016) Endothelial differentiation of canine yolk sac cells transduced with VEGF. Res Vet Sci 104: 71-76.

44. Strem BM, Hedrick MH (2005) The growing importance of fat in regenerative medicine. Trends Biotechnol 23(2): 64-66.

45. Hollands P (1987) Differentation and grafting of haemopoietic stem cells from eraly post-implantation mouse embryos. Development 99(1): 69-76.

46. Oliveira GK, Raiser AG, Olsson D (2010) Células tronco mononucleares autólogas de proteína óssea morfogenética na cicatrização de defeitos tibiais experimentais induzidos em cães. Arq Bras Med Vet Zoot 62 (1):72-79.

47. Black LL, Gaynor J, Gahring D, Adams C, Aron D, et al. (2007) Effect of adipose-derived mesenchymal stem and regenerative cells on lameness in dog with chronic osteoarthritis of the coxofemoral joints: A randomized double-blinded multicenter controlled trial. Vet Ther 8(4): 272-284.

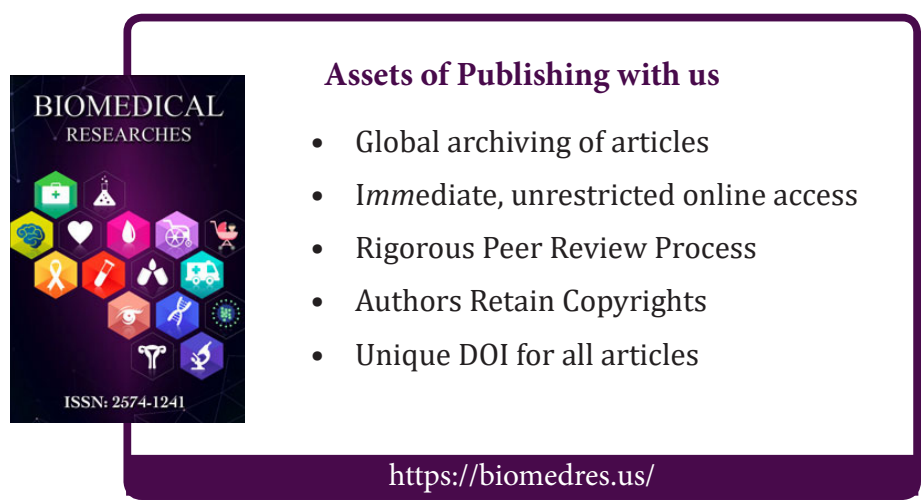

